\author{
육계분 발효사료의 첨가수준이 숫꽃사슴의 소화율, 건물채식량 \\ 및 질소출납에 미치는 영향 \\ 전병태*곽완섭**.강성기*.이상무*.문상호* \\ 건국대학교 한국녹용연구센터* \\ 건국대학교 자연과학대학 생명자원환경과학부 축산학전공**
}

\title{
Effects of Supplementary Levels of Deep-stacked Broiler Litter on Digestibility, Dry Matter Intake, and Nitrogen Balance by Male Spotted Deer(Cervus Nippon)
}

\author{
B. T. Jeon*, W. S. Kwak**, S. K. Kang*, S. M. Lee* and S. H. Moon* \\ Korea Nokyong Research Center, Konkuk University* \\ Dept. of Anim. Sci., College of Natur. Sci., Konkuk University**
}

\begin{abstract}
To determine nutritive value and suitability of deep-stacked broiler litter for deer, the influence of supplementary levels of broiler litter on digestibility, dry matter intake, and nitrogen balance was investigated in male spotted deer (Cervus nippon) fed a commercial mixed(complete) ration. The deep-stacked and ground broiler litter was supplemented at the level of $0 \%($ Control), $15 \%(\mathrm{~T} 1)$ and $30 \%$ (T2) on the basis of fresh matter to the mixed ration. All treatments had similar palatability at about 3\% body weight of dry matter intake. Dry matter digestibility was highest in Control and lowest in $\mathrm{T} 2(\mathrm{P}<0.05)$. Digestibility of crude protein was lowest $(\mathrm{P}<0.05)$ in $\mathrm{T} 2$. Dry matter and digestible dry matter intake was similar in all treatments. Daily body weight gain was not affected by treatments. Feeding 15 or $30 \%$ of broiler litter to male deer resulted in similar nitrogen intake, fecal nitrogen excretion and daily nitrogen retention $(\mathrm{g} / \mathrm{d})$, compared with feeding Control. These results suggest that up to $30 \%$ of broiler litter may be fed to male deer without deleterious effects on deer performance.
\end{abstract}

(Key words : Broiler litter, Digestibility, Intake, Nitrogen balance, Spotted deer)

\section{I. 서 론}

축산업에서 배출되는 다량의 유기성 폐기물 에 대한 처리, 특히 이들의 사료화를 통한 재 활용 시도가 최근 들어 활발히 진행되고 있으 며, 이는 축산업의 지속성을 보장하고 친환경 적 축산을 실현한다는 점에서 매우 바람직한 접근으로 평가받고 있다. 부존자원이 부족하고
경지면적이 적어 반추가축용 조사료조차 상당 부분을 수입에 의존하고 있는 우리나라 축산업 의 경우 이런 유기성 폐자원의 재활용은 매우 유용한 방안의 하나(Fontenot 등, 1983; 곽 등, 1999)가 될 수 있을 것이다.

축산 배설물 중 육계분의 경우 국내외의 육 계사육 두수가 워낙 많기 때문에 그 배출량 또 한 막대한 양에 이르고 있어 이를 처리하는데

Corresponding author : S. H. Moon, School of Life Resource Environment Science, College of Natural Sciences, Konkuk University, Chungju, Korea, 380-701, Tel:+82-43-840-3527, E-mail : moon 0204@kku.ac.kr 
상당한 비용과 노력이 요구되며 환경오염에 대 한 부담도 큰 편이다. 국내에는 2001년 말 현 재 약 60,000 천수의 육계가 사육되고 있으며 (농림부, 2002) 이들 육계는 사육기간 동안 대 략 수당 약 $1 \mathrm{~kg}$ 정도의 육계분을 생산(Malone 등, 1992)하고 있는 것으로 추정된다. 이들 대 부분은 퇴비 등으로 재활용되고 있으나 반추가 축용 사료로 재활용 할 경우 그 가치는 더욱 높아질 수 있다(Fontenot, 1990). 육계분은 NPN 이나 섬유소 및 무기물이 풍부하여(Fontenot, 1982; Jakmohla 등, 1988; Lober 등, 1992) 저질 조사료를 많이 쓰는 반추가축에게 적절히 보충 하면 반추가축용 사료자원으로서 매우 유용하 게(Fontenot과 Jurubescu, 1980; Arave 등, 1990; Chaudhry 등, 1993) 활용될 수 있을 것으로 기 대되고 있다. 사슴의 경우도 반추가축이기 때 문에 육계분을 활용하는데 큰 어려움이 없을 것으로 기대되며, 특히 사슴의 주 생산물은 녹 용으로서 녹용의 생장기간 동안에는 상당히 높 은 수준의 단백질을 요구(French 등, 1956; Liang 등, 1993) 하기 때문에 육계분의 효율적 활용으로 사료자원의 불필요한 낭비를 줄일 수 있고 그 만큼 외국에서 수입하는 사료량을 절 감할 수 있으며, 또한 폐자원의 유효한 재활용 방안이 될 수 있을 것이다. 그와 더불어 사슴 에 대한 육계분 사료의 접목에 관한 연구가 국 내외적으로 전무한 실정이기 때문에 이에 대한 연구의 필요성도 크게 요구되고 있다.

본 실험은 사슴에 대한 육계분 발효사료의 재활용 및 대체 가능성을 검토하기 위해 꽃사 슴 웅록에 있어서 육계분 발효사료의 첨가수준 이 소화율, 증체량, 건물채식량 및 질소출납에 미치는 영향을 조사하였다.

\section{․ 재료 및 방법}

\section{1. 사료제조 및 실험설계}

실험에 사용한 육계분은 1999년 9월에 충주 시 소재 육계사육농장에서 구입하였다. 왕겨를 깔개로 하여 육계를 사육한 곳에서 출하 후 일
괄 수거하였으며, 건국대학교 자연과학대학 실 습농장에서 퇴적발효공법에 의거 약 30 일간 발 효를 진행시켰다. 제조된 발효사료는 screen을 통해 이물질을 제거한 뒤 분쇄하여 분말형태로 실험에 사용하였다. 실험은 충주시 소재 하나 사슴연구소에서 2000년 6월부터 동년 10월까지 수행하였으며 사양실험을 위해 $34.6 \sim 43.2 \mathrm{~kg}$ (평 균 $38.2 \mathrm{~kg}$ )의 2 년생의 꽃사슴 웅록 4 두를 공시 하였다. 공시사슴들은 각기 분과 뇨의 분리수 거가 가능한 대사 cage에 개별 수용하였으며 실험구 배치는 처리구 3 구와 예비구 1 구를 포 함하여 $4 \times 4$ Latin square 방식에 의해 설계되 었고 각 실험기간은 예비실험 10 일과 본실험 7 일로 구성되었다.

실험사료는 $\mathrm{TDN}$ 가를 중심으로 각 처리구간 에 비슷한 수준의 $\mathrm{TDN}$ 함량이 유지되도록 Table 1과 같이 배합되었으며, 이 때 배합된 실 험사료의 화학성분 분석결과는 Table 2 와 같다. 각 실험사료에 대한 성분분석 결과, 건물 함량 은 Control구가 $84.3 \%, \mathrm{~T} 1$ 구가 $82.9 \%, \mathrm{~T} 2$ 구가 $83.6 \%$ 로 처리간에 큰 차이가 나타나지 않았으 며, 조단백질 함량은 $\mathrm{T} 1$ 구가 $16.4 \%$ 로 가장 높 았고 Control구가 $15.5 \%$ 로 가장 낮게 나타났다. 조섬유 함량은 Control 24.1\%, T1 24.4\%, T2 $26.3 \%$ 였으며 조지방 함량은 Control $4.4 \%, \mathrm{~T} 1$ $3.9 \%, \mathrm{~T} 24.1 \%$ 였다. TDN 함량은 실험사료 중 의 유기성분에 대한 각각의 소화율을 구해 $\mathrm{TDN}$ 공식을 이용하여 계산하였다. 당초 실험 사료의 제조시 에너지가를 기준으로 처리구간 $\mathrm{TDN}$ 함량이 비슷한 수준으로 유지될 수 있도 록 사료배합을 시도하였으나 실제 소화실험을 통한 TDN 함량의 분석결과 처리구간 다소의 차이가 인정되었다. 실험사료는 육계분 발효사 료의 첨가수준에 따라 $0 \%(\mathrm{Control}), 15 \%(\mathrm{~T} 1)$, $30 \%(\mathrm{~T} 2)$ 로 달리 하여 실험사슴에게 각기 오전 과 오후 하루 두 번에 걸쳐 자유채식이 가능한 정도의 충분한 양을 제공했다. 조사료는 알팔 파 베일을 Table 1 과 같은 비율로 각각의 실험 구에게 급여하였으며 모든 실험사료와 함께 정 해진 시간에 급여를 했다. 
Table 1. Ingredient composition of experimental diets

\begin{tabular}{|c|c|c|c|c|c|c|c|c|c|}
\hline \multirow{2}{*}{ Item } & \multicolumn{3}{|c|}{ Experimental diets } & \multicolumn{6}{|c|}{ Chemical composition $^{1)}$} \\
\hline & Control & $\mathrm{T} 1$ & $\mathrm{~T} 2$ & DM & $\mathrm{CP}$ & $\mathrm{EE}$ & $\mathrm{CF}$ & Ash & NFE \\
\hline & ........ & $\%$. & $\cdots \cdots$ & $\cdots \cdots$ & $\cdots 0$ & of $d$ & matte & $\ldots$ & $\cdots$ \\
\hline Commercial mixed ration & 60 & 60 & 55 & 80.3 & 17.0 & 6.1 & 18.9 & 6.6 & 51.4 \\
\hline Concentrate & 13 & 15 & 10 & 84.1 & 19.8 & 2.9 & 23.1 & 7.4 & 46.8 \\
\hline Alfalfa bale & 27 & 10 & 5 & 82.3 & 14.8 & 2.0 & 36.4 & 9.2 & 37.6 \\
\hline Broiler litter ${ }^{2}$ & 0 & 15 & 30 & 82.7 & 17.1 & 1.8 & 39.4 & 12.5 & 29.2 \\
\hline
\end{tabular}

1) DM : dry matter, CP : crude protein, EE : ether extracts, CF : crude fiber, NFE : nitrogen free extract.

2) Deep-stacked.

Table 2. Chemical composition of experimental diets

\begin{tabular}{|c|c|c|c|}
\hline \multirow{2}{*}{ Item } & \multicolumn{3}{|c|}{ Experimental diets } \\
\hline & Control & $\mathrm{T} 1^{1)}$ & $\mathrm{T} 2^{2)}$ \\
\hline & .......... & Iry me & ....... \\
\hline Dry matter & 84.3 & 82.9 & 83.6 \\
\hline Crude protein & 15.5 & 16.4 & 16.2 \\
\hline Ether extract & 4.4 & 3.9 & 4.1 \\
\hline Crude fiber & 24.1 & 24.4 & 26.3 \\
\hline Crude ash & 7.0 & 8.0 & 8.5 \\
\hline Nitrogen free extract & 49.0 & 47.3 & 44.9 \\
\hline $\mathrm{TDN}^{3)}$ & 70.6 & 70.9 & 69.1 \\
\hline
\end{tabular}

1) including $15 \%$ of broiler litter.

2) including $30 \%$ of broiler litter.

3) calculated value.

\section{2. 시료의 화학성분 및 통계분석}

건물 및 각 성분의 소화율은 전분채취법에 의해 구했으며, 채식량은 매회 사료급여시 잔 량을 측정하여 급여량에서 잔량을 제한 값을 건물 함량 기준으로 채식량을 계산했다. 질소 출납 시험은 소화시험과 동시에 진행되었으며 매일 분리된 분과 뇨를 각각 수거, 그 중 일정 량을 무작위 채취하여 분은 즉시 통풍건조기에 서 건조하였고 뇨는 $5^{\circ} \mathrm{C}$ 의 냉장고에서 분석 때 까지 보관하였다. 질소출납 시험시 뇨 중의 질 소성분 휘발을 방지하기 위해 수거용기는 입구 가 좁은 프라스틱통을 이용했으며 $3 \mathrm{~N}$ 의 $\mathrm{HCl}$ 을 $20 \mathrm{ml}$ 씩 매일 보충하였다. 채취사료, 잔사, 분, 뇨에 대한 각각의 일반성분은 상법(A.O.A.C,
1990)에 의해 분석하였으며 분석 및 획득된 결 과의 유의성을 검증하기 위해 통계분석은 $\mathrm{SAS}$ package(1996)를 이용하여 분산분석 후 General linear model을 이용한 Duncan 다중분석을 사용 했다.

\section{III. 결과 및 고찰}

Fig. 1은 실험기간 중 실험사료에 대한 숫사 슴의 채식기호도를 나타낸 것인데 실험개시시 처리간에 다소의 채식량 차이가 존재하여 $\mathrm{T} 2$ 구 가 나머지 두 구에 비해 낮은 채식성이 인정되 었으나 이후 모든 처리구에서 비슷한 수준의 채식량을 나타냈다. 또한 모든 처리구에서 공 시된 사슴들이 건물기준으로 체중의 약 $3 \%$ 정 


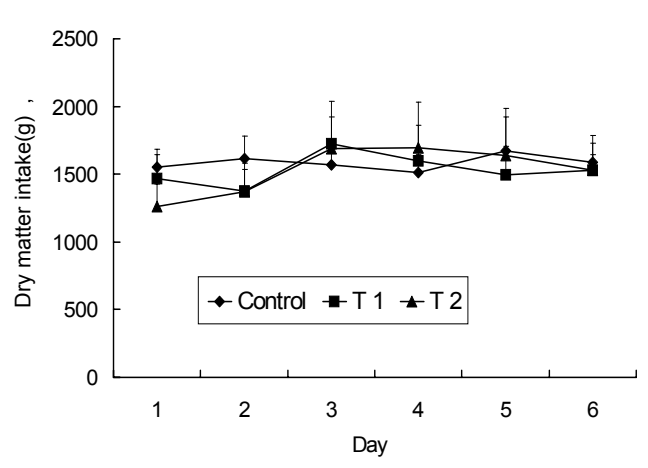

Fig. 1. Daily change in dry matter intake by male spotted deer fed experimental diet during the experimental period.

도의 채식량을 기록하고 있어 육계분 발효사료 를 $30 \%$ 까지 첨가한 경우 숫사슴의 채식 기호 도 및 사료적응에는 부정적인 영향이 나타나지 않는 것으로 판단되었다.

Table 3은 숫사슴에 있어서 육계분 발효사료 의 첨가수준에 따른 건물, 조단백질, 조섬유 및 조지방의 소화율을 나타낸 것이다. 건물소화율 은 Control이 $76.5 \%$ 로 가장 높았고 T2가 $70.3 \%$ 로 가장 낮아 유의성 $(\mathrm{P}<0.05)$ 이 인정되었다. 조 단백질의 경우도 Control구가 $75.8 \%$ 로 가장 높 은 소화율을 나타냈으며 $\mathrm{T} 2$ 가 $70.2 \%$ 로 가장 낮은 소화율을 나타내어 처리간에 유의성 $(\mathrm{P}<$ 0.05 )이 인정되었다. 조섬유 소화율은 Control구 $70.8 \%$, T1구 $62.7 \%, \mathrm{~T} 2$ 구 $56.0 \%$ 로 육계분 발 효사료의 첨가수준이 높아짐에 따라 조섬유 소 화율이 저하되어 Control구와의 사이에 유의성 $(\mathrm{P}<0.05)$ 이 인정되었다. 본 실험에서 육계분 발
효사료의 첨가수준에 따른 소화율의 저하는 $\mathrm{T} 2$ 구에서 비교적 명확했으며 특히 채식량이 비슷 한 수준으로 유지되었음에도 불구하고 $\mathrm{T} 2$ 구의 소화율 저하가 뚜렷하게 나타난 것은 다른 물 리적 요인에 의해 영향을 받은 것으로 여겨진 다. 급여된 실험사료 중 육계분 발효사료의 경 우는 퇴적발효 후 펠렛화 된 것을 사료배합을 위해 분쇄하여 분말화 하였기 때문에 다른 사 료들에 비해 상대적으로 사료입자도가 작았으 며, 이것이 소화관내 통과속도를 높였기 때문 에 건물소화율의 상대적인 저하를 가져온 것으 로 판단된다. 일반적으로 사료의 입자도는 건 물채식량이나 소화율에 직접적으로 영향을 미 치는 요인으로서, 입자도의 저하는 사료의 소 화관내 통과속도를 증가시켜 소화율을 저하 (Kato 등, 1989) 시키는 것으로 알려져 있다. 따라서 사료입자도가 작은 육계분 발효사료의 혼합비율이 높은 $\mathrm{T} 2$ 구의 경우 사료입자의 반추 위내 체류시간의 상대적인 감소로 인해 소화효 율이 낮아진 것으로 추정되고 있다. 한편 Patil 등(1995)은 육계분 사료의 반추위내 체류시간 이 증가하여도 소화율에는 영향을 미치지 않는 다고 보고했는데 이는 육계분 사료 중에 포함 된 왕겨와 같은 난용성 성분을 많이 포함하는 물질의 혼입 정도에 의한 것으로 판단되며, 특 히 $\mathrm{T} 2$ 구의 소화율 저하는 조섬유(Table 1)를 비롯한 불용성의 성분이 다량 함유되었기 때문 에 나타나는 현상으로 여겨진다. 또한 Rossi 등 (1996; 1998)은 육계분 사료의 입자도는 건물 및 $\mathrm{NDF}$ 소화율에 영향을 미친다고 보고하였 고, Al-Rokayan 등(1998)도 육계분 사료의 혼합

Table 3. Digestibility of nutrients by male spotted deer fed experimental diets

\begin{tabular}{cccc}
\hline & \multicolumn{3}{c}{ Experimental diet } \\
\cline { 2 - 4 } Item & Control & $\mathrm{T} 1$ & $\mathrm{~T} 2$ \\
\hline \hline Digestibility(\%) & & & \\
Dry matter & $76.5 \pm 3.6^{\mathrm{a}}$ & $74.7 \pm 7.6^{\mathrm{ab}}$ & $70.3 \pm 8.8^{\mathrm{b}}$ \\
Crude protein & $75.8 \pm 3.9^{\mathrm{a}}$ & $76.4 \pm 6.6^{\mathrm{a}}$ & $70.2 \pm 8.8^{\mathrm{b}}$ \\
Crude fiber & $70.8 \pm 4.3^{\mathrm{a}}$ & $62.7 \pm 11.9^{\mathrm{ab}}$ & $56.0 \pm 13.6^{\mathrm{b}}$ \\
Ether extract & $87.1 \pm 1.9^{\mathrm{a}}$ & $79.7 \pm 5.9^{\mathrm{b}}$ & $85.4 \pm 5.7^{\mathrm{ab}}$ \\
\hline
\end{tabular}

a,b Means with different superscripts in the same row are significantly $\operatorname{different}(\mathrm{P}<0.05)$. 
비율이 일정비율 이상이 되면 소화율의 저하를 나타내며 이는 주로 육계분 사료 중에 함유된 난용성의 물질에 의한 것으로 보고하고 있어 본 실험의 결과를 뒷받침 해 주고 있다.

Fig. 2는 육계분 발효사료의 첨가수준에 따른 건물 및 가소화 건물섭취량을 나타낸 것이다. 건물 및 가소화 건물섭취량 모두 육계분 발효 사료의 첨가수준이 높아질수록 약간씩 저하되 는 경향은 있었으나 그 차이에 대한 유의성은 인정되지 않았다. 동일한 사료조건으로 암사슴 에 대한 실험(전 등, 2001)에서는 육계분 발효 사료를 $30 \%$ 첨가한 처리구에서 채식량이 많았 으나 소화율의 차이로 인해 가소화 건물섭취량 은 비슷한 수준이 유지되었던 결과를 나타냈는 데 본 실험에서도 결과적으로 건물 및 가소화 건물섭취량의 처리간 차이는 거의 인정되지 않 았다. 선행 연구결과들에서는 산란계분 및 육 계분 사료를 첨가한 경우 대부분 계분의 첨가 가 채식량의 증가를 가져온 것으로 보고(고와 안, 1998; Kim 등, 1993)되고 있다. 또한 Rossi 등(1996)은 육계분 발효사료를 첨가하는 경우 육계분의 낮은 $\mathrm{NDF}$ 소화율에도 불구하고 건물 및 $\mathrm{OM}$ 채식량의 저하는 나타나지 않았으며 이는 계분사료의 가용성 성분을 중심으로 한 보상채식(Tagari 등, 1976; Patil 등, 1993)이 주 된 원인으로 보고하고 있다. 본 실험에서도 육 계분 발효사료의 첨가수준에 따라 건물을 비롯

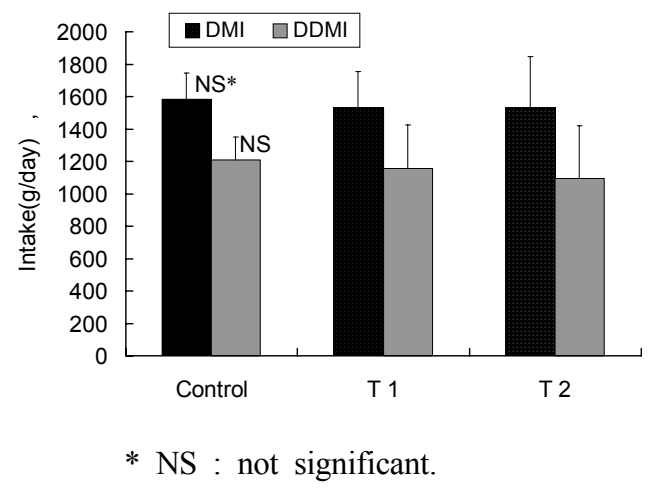

Fig. 2. Dry matter intake(DMI) and digestible dry matter intake(DDMI) by male spotted deer fed experimental diets.
영양소의 소화율이 낮았음에도 불구하고 건물 섭취량 및 가소화 건물섭취량의 차이가 없었던 것도 이런 측면에서 추정해 볼 수 있을 것으로 판단된다. 따라서 사슴용 사료에 $30 \%$ 전후의 계분사료 첨가는 채식량에 부정적인 영향을 미 치지 않는 것으로 추정된다.

Fig. 3은 육계분 발효사료의 첨가수준에 따른 수사슴의 일당증체량을 나타낸 것이다. 실험사 슴들의 일당 증체량은 $\mathrm{T} 1$ 구에서 가장 높았으며 Control구에서 가장 낮았으나 처리간의 차이는 유의성이 인정되지 않았다. 이는 건물 및 가소 화 건물채식량이 비슷한 수준을 유지했기 때문 에 생산성의 차이가 없었던 것으로 판단되며, $\mathrm{T} 1$ 구의 높은 증체량은 질소의 체내 축적량 (Table 4)이 다른 두 처리구에 비해 높았던 것 에 기인한 것으로 여겨진다.

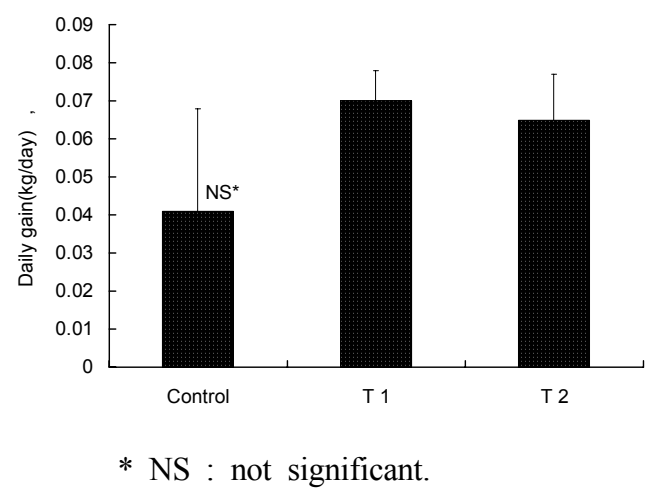

Fig. 3. Daily gain of male spotted deer fed experimental diets.

실험기간 중 실험사슴에 있어서 영양소의 체 내 이용성을 측정하기 위해 실시한 질소출납실 험의 결과를 Table 4에 나타냈다. 질소섭취량은 $\mathrm{T} 1$ 구가 $40.2 \mathrm{~g}$ 으로 가장 많았으며 $\mathrm{T} 2$ 구가 $38.0 \mathrm{~g}$ 으로 가장 낮았으나 처리간의 유의성은 인정되 지 않았다. 분으로 배출된 질소의 양은 $\mathrm{T} 2$ 구에 서 가장 높았으며 뇨속에 포함되어 배출된 질 소의 양은 Control구가 가장 높았다 $(\mathrm{P}<0.05)$. 이 에 따라 질소의 체내 축적량은 $\mathrm{T} 1$ 구에서 가장 많았으며 나머지 두 처리구는 다소 적었으나 비슷한 수준을 유지했다. 육계분 첨가 사료의 경우 육계분속의 높은 질소 함량으로 인해 첨 
Table 4. Nitrogen balance of male spotted deer fed experimental diets

\begin{tabular}{|c|c|c|c|}
\hline \multirow{2}{*}{ Item } & \multicolumn{3}{|c|}{ Experimental diet } \\
\hline & Control & $\mathrm{T} 1$ & $\mathrm{~T} 2$ \\
\hline Nitrogen balance & $\ldots \ldots \ldots \ldots \ldots$ & $\cdots \cdots \cdot$ g/day & n............ \\
\hline Nitrogen intake(NI) & $39.2 \pm 4.0^{\mathrm{a}}$ & $40.2 \pm 5.8^{\mathrm{a}}$ & $38.0 \pm 7.4^{\mathrm{a}}$ \\
\hline Fecal nitrogen & $9.4 \pm 1.8^{\mathrm{a}}$ & $9.2 \pm 1.8^{\mathrm{a}}$ & $10.3 \pm 2.4^{\mathrm{a}}$ \\
\hline Digestible nitrogen & $29.7 \pm 3.4^{\mathrm{a}}$ & $31.0 \pm 6.9^{\mathrm{a}}$ & $27.7 \pm 7.7^{\mathrm{a}}$ \\
\hline Urinary nitrogen & $10.9 \pm 6.2^{\mathrm{a}}$ & $7.1 \pm 2.8^{b}$ & $7.2 \pm 3.9^{b}$ \\
\hline Retained nitrogen(RN) & $18.8 \pm 6.5^{\mathrm{a}}$ & $23.9 \pm 7.2^{\mathrm{a}}$ & $20.5 \pm 7.6^{\mathrm{a}}$ \\
\hline $\mathrm{RN} / \mathrm{NI}(\%)$ & $48.2 \pm 15.9^{\mathrm{a}}$ & $58.5 \pm 10.5^{\mathrm{a}}$ & $53.9 \pm 14.1^{\mathrm{a}}$ \\
\hline
\end{tabular}

a,b Means with different superscripts in the same row are significantly different $(\mathrm{P}<0.05)$.

가비율에 따라서는 질소의 섭취량이 증가하고 더불어 분과 뇨로 배출되는 질소량도 증가 $(\mathrm{Kim}$ 등, 1993; 류 등, 1995; Bakshi와 Fontenot, 1998) 되는 것으로 선행 연구결과인 전 등 (2001)에서 보고되고 있다. 특히 많은 질소를 함유한 육계분 속의 질소화합물은 반추위 내에 서 분해가 전형적으로 광범위하고 빠르게 진행 되며 가용성 탄수화물의 함량이 적기 때문에 질소이용 효율이 낮아지며(Patil 등, 1995; Fontenot, 1990) 과도한 반추위내 암모니아 농도로 인해 뇨로 배출되는 질소의 양도 증가하고 그 로 인해 간장에서의 요소합성을 위해 소비하는 에너지도 많아진다는(Huntington, 1990) 연구결 과들이 보고되고 있다. 그러나 본 실험에서는 공시된 육계분 발효사료의 질소 함량이 다른 연구보고(Harmon 등, 1974; Bhattacharya와 Taylor, 1975)에 비해 낮았기 때문에 상대적으 로 Control구와 비슷한 수준의 질소 섭취량을 나타내었으며 육계분 발효사료의 첨가수준이 증가되어도 뇨중에 포함되어 배출된 질소량은 높지 않았다. 따라서 육계분 발효사료의 첨가 수준에 따른 질소의 체내 축적량은 큰 차이가 없이 비슷한 수준으로 유지되었다. 한편 선행 연구(전 등, 2001)에서의 암사슴에 비해서는 숫 사슴의 경우가 다소의 체중차이는 있었으나 질 소 섭취량과 더불어 질소 축적량도 높은 경향 을 나타냈다.

결과적으로 육계분 발효사료의 첨가수준이 $30 \%$ 정도까지는 숫사슴의 경우도 암사슴과 마 찬가지로 건물채식량이나 영양소의 소화율 및
이용성에 부정적인 영향이 없는 것으로 여겨진 다. 따라서 육계분 발효사료는 사슴에게 있어 서 단백질과 섬유소를 공급하는 사료자원으로 서 활용 가능성이 충분하다고 판단되었다.

$$
\text { IV. 요 약 }
$$

본 실험은 기존 사슴사료에 있어서 육계분 발효사료의 대체 가능성을 검토하기 위해 숫사 슴에 있어서 육계분 발효사료의 첨가수준을 0 , 15 , 및 $30 \%$ 로 달리하여 소화율, 증체량, 건물 채식량 및 질소출납에 미치는 영향을 검토하였 다. 모든 처리구에서 실험사슴들은 비슷한 수 준의 채식량을 나타내어 건물기준으로 체중의 약 $3 \%$ 정도의 채식량을 기록하고 있어 육계분 발효사료를 $30 \%$ 까지 첨가한 경우 숫사슴의 채 식 기호도에는 부정적인 영향이 나타나지 않는 것으로 판단되었다. 건물소화율은 Control이 $76.5 \%$ 로 가장 높았고, $\mathrm{T} 2$ 가 $70.3 \%$ 로 가장 낮 아 유의성 $(\mathrm{P}<0.05)$ 이 인정되었다. 조단백질의 경우도 Control구가 $75.8 \%$ 로 가장 높은 소화율 을 나타냈으며, $\mathrm{T} 2$ 가 $70.2 \%$ 로 가장 낮은 소화 율을 나타내어 처리간에 유의성 $(\mathrm{P}<0.05)$ 이 인정 되었다. 조섬유 소화율은 Control구 $70.8 . \%, \mathrm{~T} 1$ 구 $62.7 \%, \mathrm{~T} 2$ 구 $56.0 \%$ 로 육계분 발효사료의 첨가수준이 높아짐에 따라 조섬유 소화율이 저 하되어 Control구와의 사이에 유의성 $(\mathrm{P}<0.05)$ 이 인정되었다. 건물 및 가소화 건물섭취량 모두 육계분 발효사료의 첨가수준이 높아질수록 약 
간씩 저하되는 경향은 있었으나 그 차이에 대 한 유의성은 인정되지 않았다. 실험사슴들의 일당 증체량은 $\mathrm{T} 1$ 구에서 가장 높았으며 Control구에서 가장 낮았으나 처리간의 차이는 유 의성이 인정되지 않았다. 질소섭취량은 $\mathrm{T} 1$ 구가 $40.2 \mathrm{~g}$ 으로 가장 많았으며 $\mathrm{T} 2$ 구가 $38.0 \mathrm{~g}$ 으로 가 장 낮았으나 처리간의 유의성은 인정되지 않았 다. 분 중 질소의 양은 $\mathrm{T} 2$ 구에서 가장 높았으 며 뇨 중 질소의 양은 Control구가 가장 높았다 $(\mathrm{P}<0.05)$. 체내 질소 축적량은 $\mathrm{T} 1$ 구에서 가장 높았으나 나머지 처리구들과 비슷한 수준을 유 지했다.

\section{$\mathrm{V}$. 인 용 문 헌}

1. AOAC. 1990. Official Methods of Analysis. (15th ed.) Association of Official Analytical Chemists. Washington, D. C., U.S.A.

2. Al-Rokayan, S. A., Naseer, Z. and Chaudhry, S. M. 1998. Nutritional quality and digestibility of sorghum-broiler litter silages. Anim. Feed Sci. Technol. 75:65-73.

3. Arave, C. W., Dobson, D. C., Stenquist, N. J. and Walters, J. L. 1990. Poultry waste as a supplement to grass hay for wintering beef steers and heifers, Proc. West. Sect. A. S. A. S. 41:345-351

4. Bakshi, M. P. S. and Fontenot, J. P. 1998. Processing and nutritive evaluation of broiler litter as livestock feed. Anim. Feed Sci. Technol. 74: 337-345.

5. Bhattacharya, A. N. and Taylor, J. C. 1975. Recycling animal waste as a feedstuff: a review. J. Anim. Sci. 41:1438-1457.

6. Chaudhry, S. M., Naseer, Z. and Chaudhry, D. M. 1993. Fermentation characteristic and nutritive value of broiler litter ensiled with corn forage. Food Chem. 48:51-55.

7. Fontenot, J. P. and Jurubescu, V. 1980. Processing of animal waste by feeding to ruminants. In: Y. Ruckebusch and P. Thivend(ed.), Digestive Physiology and Metabolism in Ruminants. AVI. Westport, CT. pp. 641-662.

8. Fontenot, J. P. 1982. Assessing animal-waste feeding: nutritional guideline and safety considerations. Anim. Nutr. and Health. 37:12-15.

9. Fontenot, J. P., Smith, L. W. and Sutton, A. L. 1983. Alternative utilization of animal wastes. J. Anim. Sci. 57(suppl. 2):221-233.

10. Fontenot, J. P. 1990. Recycling animal waste by feeding to enhance environmental quality. In: Animal Agriculture for the 90's. Amer. Feed Ind. Assoc., Arlington. VA. pp. 56-72.

11. French, C. E., McEwen, L. E., Magruder, N. D., Ingram, R. H. and Swift, R. W. 1956. Nutrient requirement for growth and antler development in the white-tailed deer. J. Wildl. Manage. 20:221232.

12. Harmon, B. W., Fontenot, J. P. and Webb, K. E. Jr. 1974. Effect of processing method of broiler litter on nitrogen utilization by lambs. J. Anim. Sci. 39:942-948.

13. Huntington, G. B. 1990. Energy metabolism in the digestive tract and liver of cattle: influence of physiological state and nutrition. Reprod. Nutr. Develop. 30:35-47.

14. Jakmohla, R. C., Kinduu, S. S., Punj, M. L., Sing, K., Kamra, D. N. and Sing, R. 1988. Animal excreta as ruminant's feed-scope and limitation under indian conditions. Anim. Feed Sci. Technol. 19:1-23.

15. Kato, K., Kajima, Y., Odashima, M., Lee, S. L., Nam, K. T., Chiga, H., Otomo, Y., Shoji, H., Otha, M. and Sasaki, Y. 1989. Feed passage and digestibility in Japanese deer and sheep. Research Report of Kawatabi Experimental Station. 5:5962.

16. Kim, J. H., Yokota, H., Ko, Y. D., Okajima, T. and Ohshima, M. 1993. Nutritional quality of whole crop corn forage ensiled with cage layer manure. I. Quality, voluntary feed intake and digestibility of the silages in goat. Asian-Aus. J. Anim. Sci. 6(1):45-51.

17. Liang, F., Wang, Q. and Wen, T. 1993. Deer feeding for velvet production. Proc. the 4th ARRC Inten. Symposium. Konkuk University. pp. 115-122.

18. Lober, U., Eisengarten, H. J. and Flachowsky, G. 1992. A field study on the influence of urea on 
microbial decontamination and digestibility of broiler litter. Bioresource Technol. 41:135-138.

19. Malone, G. W., Gedamu, N. and Sims, J. T. 1992. Delmarva broiler litter production rates. Poult. Sci. 71:52.

20. Patil, A. R., Goetsch, A. L., Kouakou, B., Galloway, D. L., Sr., L. A. Forster Jr. and Park, K. K. 1995. Effects of corn vs. corn plus wheat in forage-based diets containing broiler litter on feed intake, ruminal digesta characteristics and digestion in cattle. Anim. Feed Sci. and Technol. 55:87-103.

21. Patil, A. R., Goetsch, A. L., Galloway, D. L. Sr. and Forster, L. A. Jr. 1993. Intake and digestion by Holstein steer calves consuming grass hay supplemented with broiler litter. Anim. Feed Sci. Technol. 44: 251-263.

22. Rossi, J. E., Goetsch, A. L. and Galloway, D. L. Sr. 1998. Intake and digestion by Holstein steers consuming different particle size fractions of broiler litter. Anim. Feed Sci. Technol. 71:145156

23. Rossi, J. E., Goetsch, A. L., Patil, A. R., Kouakou, B., Park, K. K., Wang, Z. S., Galloway, D. L. Sr. and Johnson, Z. B. 1996. Effects of forage level in broiler litter-based diets on feed intake, digestibility and particulate passage rate in Holstein steers at different live weights. Anim. Feed Sci. Technol. 62:163-177.

24. SAS. 1996. SAS User's Guide : Statistics, statistical analysis system. Inc. Cary, NC.

25. Tagari, H., Levy, D. and Holzer, Z. 1976. Poultry litter for intensive beef production. Anim. Prod. 23:317-327.

26. 고영두, 안병관. 1998. 옥수수 계분 Silage 제조실 험. ㅍ. Silage의 소화율 및 기호성. 한국축산학 회지. 30(2):98-102.

27. 곽완섭, 허정원, 정동관. 1999. 현장규모로 제조 된 육계분 발효사료의 일반적 특성 및 위생적 안전성 평가. 한국낙농학회지. 21(4):269-278.

28. 농림부. 2002. 농업통계. 농림부 홈페이지.

29. 류영우, 고영두, 구재윤, 김재황, 유성오, 이희석. 1995. 면양에 있어서 수수-계분 Silage의 영양 소 함량, 소화율, 질소출납 및 기호성. 한국축산 학회지. 37(2):151-158.

30. 전병태, 문상호, 권영재, 곽완섭. 2001. 육계분 발 효사료의 첨가수준이 꽃사슴의 건물섭취량, 소화 율 및 질소 출납에 미치는 영향. 한국동물자원과 학회지. 43(5):727-734.

(접수일자 : 2002. 9. 9 / 채택일자 : 2002. 12. 10) 